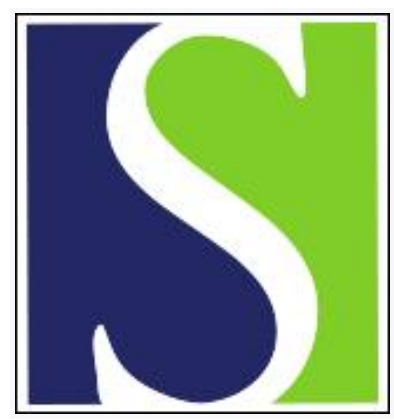

Scand J Work Environ Health 2008;34(1):66-72

https://doi.org/10.5271/sjweh.1191

Issue date: 29 Feb 2008

Asthma incidence in wood-processing industries in Finland in a register-based population study

by Heikkilä P, Martikainen R, Kurppa K, Husgafvel-Pursiainen K, Karjalainen A

Affiliation: Finnish Institute of Occupational Health, Topeliuksenkatu 41 aA, FI-00250 Helsinki, Finland. pirjo.heikkila@ttl.fi

Key terms: asthma; asthma incidence; attributable fraction; exposure; Finland; incidence; occupational disease; population study; register-based study; relative risk; wood dust; wood-processing industry

This article in PubMed: www.ncbi.nlm.nih.gov/pubmed/18427700

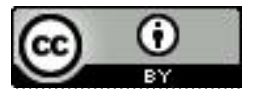




\title{
Asthma incidence in wood-processing industries in Finland in a register- based population study
}

\author{
by Pirjo Heikkilä, PhD, ${ }^{1}$ Rami Martikainen, MSc, ${ }^{1}$ Kari Kurppa, MD, ${ }^{1}$ Kirsti Husgafvel-Pursiainen, PhD, ${ }^{1}$ \\ Antti Karjalainen, $M D^{1}$
}

\begin{abstract}
Heikkilä P, Martikainen R, Kurppa K, Husgafvel-Pursiainen K, Karjalainen A. Asthma incidence in wood-processing industries in Finland in a register-based population study. Scand J Work Environ Health. 2008;34(1):66-72.
\end{abstract}

\begin{abstract}
Objectives This register-based population study determined incidence rates of clinically verified asthma among woodworkers, other blue-collar workers, and administrative personnel employed in wood-processing industries in Finland. Exposure to wood dust was under special scrutiny.

Methods All Finns employed in wood-processing industries were followed for asthma incidence via record linkage in the years 1986-1998. Incident cases included people with asthma reimbursed for medication by the national health insurance or registered as having occupational asthma. Age-adjusted incidence rates and relative risks (RR) by gender were estimated for wood workers, other blue-collar workers, and administrative employees (referents) in wood industries.

Results The relative risk of asthma was increased for all woodworkers among both genders [men: RR 1.5, 95\% confidence interval (95\% CI) 1.2-1.8; women: RR 1.5, 95\% Cl 1.2-1.7]; a similarly elevated risk was also found for other blue-collar workers (men: RR 1.5, 95\% Cl 1.2-1.8; women: RR 1.4, 95\% Cl 1.2-1.6) in the same wood industries. Statistically increased relative risks were found for low and medium exposure to wood dust, but not for high exposure. Altogether 217 of the 4074 clinically verified asthma cases were reported as occupational asthma in the Finnish Register on Occupational Diseases.

Conclusions The incidence rates for asthma were significantly increased both among the woodworkers and the other blue-collar workers in wood industries but without a clear dose-response. Cases recognized as occupational asthma accounted for only a small part of the total asthma excess, indicating that much of the work-related asthma excess remains unrecognized in these industries.
\end{abstract}

Key terms attributable fraction; exposure; occupational disease; relative risk; wood dust.

Asthma is a common disorder; $5-10 \%$ of the general population in many countries is affected by the disease. A recent Finnish study indicated that the attributable fraction of work in adult-onset asthma is $29 \%$ for men and $17 \%$ for women (1). Other studies suggest that the proportion of new or exacerbated asthma cases due to workplace exposures ranges between $9 \%$ and $26 \%$ (2-6). Although over 250 agents have been documented as being responsible for sensitizer-induced occupational asthma, our knowledge about the multiplicity of causative factors and the pathogenic mechanisms involved in the development of occupational asthma still remains incomplete (7).

As concerns work in wood processing, asthma has been attributed to dust from many different tree species, on the basis of case reports and epidemiologic studies (8, 9). The proportion of all cases of occupational asthma due to wood dust has been reported to be some 6-11\% (8). Asthma induced by western red cedar has been frequently documented for sawmill workers, with an apparent dose-response relationship (10-14). The studies proposing a relationship between exposure to other softwood species and asthma have used self-reported asthma (11) and clinically diagnosed asthma $(15,16)$ as outcomes.

Finland provides an opportunity to study the variation in asthma incidence in a country in which the cost of asthma medication for clinically verified asthma is reimbursed and registered by a national health insurance scheme that covers the entire population. A personal identification code allows linkage of the register information with data on employment and occupation available from the Finnish Population Census. The results from such data linkage have identified a large number

Correspondence to: Dr P Heikkilä, Finnish Institute of Occupational Health, Topeliuksenkatu 41 aA, FI-00250 Helsinki, Finland. [E-mail: pirjo.heikkila@ttl.fi] 
of occupations with significant excesses of asthma incidence rates (1).

Specific bronchial challenge testing of individual workers has shown that wood dusts common in Finnish industries (spruce, pine, birch) cause asthma. A few cases a year are registered in the Finnish Register on Occupational Diseases. Yet it is not known how high the risk actually is and which industrial sectors may be particularly at risk. Therefore, our present analysis compared the incidence rate of asthma in a variety of Finnish wood-processing industries. We used the data from the national reimbursement register for asthma medication, the Finnish Register on Occupational Diseases, and the Finnish Population Census for the occupation and industrial sector of employment from three census cohorts $(1985,1990$, and 1995) to estimate the incidence rates of asthma for woodworkers in wood-processing industries.

\section{Study population and methods}

\section{Study population and design}

All Finns who were 20-59 years old, without preexisting asthma on 31 December 1985, 1990, and 1995, and who were employed according to the population census in 1985, 1990, or 1995 in certain industrial sectors were followed for asthma incidence rates during the years 1986-1990, 1991-1995, and 1996-1998, respectively. The industrial sectors included in the asthma followup were as follows (the codes are those used by the Statistical Classification of Economic Activities in the European Community, NACE Rev 1, 1990): (i) forestry, logging and related services (02.0), (ii) sawmilling and planing of wood and impregnation of wood (20.1), (iii) manufacture of veneer sheets and manufacture of plywood, laminboard, particle board, fiber board and other panels and boards (20.2), (iv) manufacture of builders' carpentry and joinery (20.3), (v) manufacture of wooden containers (20.4), (vi) manufacture of other products of wood and manufacture of articles of cork, straw and plaiting materials (20.5), (vii) building and repairing of ships and boats (35.1), (viii) manufacture of furniture (36.1), (ix) building of complete constructions or parts thereof and civil engineering (45.2), and (x) building completion (45.4).

On the average, about 158000 blue-collar workers (141 187 men and 16937 women) and about 13000 administrative workers (4628 men and 8211 women) in the three census cohorts were employed in these woodprocessing industries.

The follow-up was performed using the unique personal identification code in accessing two national registers, the Drug Reimbursement Register of the Social
Insurance Institution of Finland and the Finnish Register on Occupational Diseases, housed in the Finnish Institute of Occupational Health. Duplicate notifications in two registers were identified using the indivitual personal identification codes. For each follow-up period, the cases and person-years were calculated according to occupation and the sector of economic activity in which the person was working at the start of the follow-up. People could contribute to the person-years of several follow-up periods, provided they had not been defined as an incident case of asthma before the start of the follow-up period and were still employed in the selected industrial sectors at the start of the follow-up period. Therefore, the number of persons under followup is given as an average of the three follow-up periods and not as an absolute number of the different persons followed. The occupation was known for $99 \%$ of those employed in each of the three censuses. The study protocol was approved by the ethics committees of the participating institutions.

\section{Classification of occupation of the persons and eco- nomic activity of their employers}

Information on the professional status, current occupation, and economic activity of employees is recorded for every employed person in the Finnish Population Census. The occupational codes are based on a version of the International Standard Classification of Occupations, 1988 (ISCO-88 COM). The economic activity codes partly follow an extended classification of the Standards Industrial Classification of all Economic Activities by the United Nations in 1968 and partly the Statistical Classification of Economic Activities in the European Community, 1990 (NACE Rev 1). All of the economic activity codes were converted to NACE Rev 1.

Information on occupation was cross-sectional from the time of the census. Those aged $<20$ years were not followed because a change of occupation and migration between education and worklife make the employment status and occupation at the start of the follow-up less reliable indicators of the occupational status during the 5 -year follow-up. Similarly those aged $>59$ years were not followed because most of those employed at the start of the follow-up would no longer have been employed at the end of the follow-up; the time period when they left the labor market was not known.

\section{Occupational exposure to wood dust}

The occupations in the selected 10 wood industries were grouped into the following three categories: woodworkers (with direct exposure to wood dust), other blue-collar workers (with possible exposure to wood dust), and unexposed persons (administrative workers; reference 
group). The jobs coded as woodworkers were forestry workers and lumberjacks, timber men, sawyers, plywood and fiberboard workers, construction carpenters, wooden boat builders, coach-body builders, bench carpenters, cabinetmakers and joiners, woodworking machine operators, wooden surface finishers, woodworking occupations not elsewhere classified, and cleaners. The group of other blue-collar workers in wood-processing industries consisted of workers with such occupations as technicians, painters, welders, assemblers, machine mechanics, forklift and other drivers, and packers. Some persons in this group have also been exposed to wood dust, including mechanics and assemblers when repairing wood-processing machines. Those employed in administrative, managerial, and clerical work in the selected industries were considered to be unexposed and were used as a reference group. The incidence rates for asthma in these three occupational groups in the selected 10 industrial sectors were followed.

Incidence rates were also calculated according to the estimated level of wood dust exposure. Occupational exposure to wood dust was assessed in 120 job-industry combinations as an annual mean of the total dust concentration. [Total dust concentrations correspond to approximately $50 \%$ of the inhalable dust concentration.] The workers in the 10 selected industrial sectors were classified into the following five categories: high, medium or low exposure to wood dust, unknown exposure, and reference group (table 1). The classification of exposure levels was based on measurements carried out by the Finnish Institute of Occupational Health in the selected industrial sectors (17).

\section{Definition and ascertainment of cases}

Incident cases were collected from the Medication Reimbursement Register of the Social Insurance Institution. In Finland, asthma is classified as a chronic disease for which the cost of medication can be reimbursed at a higher than ordinary level. To receive the compensation, the patient has to apply for the entitlement from the Social Insurance Institution, submitting a medical

Table 1. Wood-dust exposure categories for woodworkers and the number of job-industry combinations in each category.

\begin{tabular}{lcc}
\hline Category & $\begin{array}{c}\text { Total dust concentration } \\
\left(\mathrm{mg} / \mathrm{m}^{3}\right)\end{array}$ & $\begin{array}{c}\text { Number of job-industry } \\
\text { combinations }\end{array}$ \\
\hline Low & $0.02-<0.5$ & 68 \\
Medium & $0.5-<1.5$ & 40 \\
High ${ }^{\mathrm{a}}$ & $\geq 1.5$ & 12 \\
\hline
\end{tabular}

a Jobs classified as high exposure (the codes refer to economic activity codes; see the Classification of Occupation of the Persons and Economic Activity of their Employers section for details): timber men (45.4), sawyers (36.1 \& 45.4), woodworking machine operators (20.3 \& 36.1), bench carpenters, cabinetmakers, joiners, etc ( $36.1 \& 45.4)$, cleaners (20.1, $20.2 \& 36.1)$. certificate signed by a pulmonary specialist, along with the application. For compensation to be granted, the disease has to fulfill the diagnostic and severity criteria of asthma (1), including objective data of reversible bronchial obstruction and a persistent pattern of disease. The health insurance, which includes the drug-reimbursement system, covers the entire Finnish population, and consequently all Finnish patients with asthma fulfilling the criteria are identifiable in the register. The only exceptions are patients with recognized occupational asthma, who receive full compensation for medication from the Statutory Accident Insurance. The recognition of occupational asthma necessitates a diagnosis of asthma made by a pulmonary specialist and his or her evidence of a specific causal association between the person's occupational exposure and the disease.

In our current study, a person was defined as having clinically verified asthma if he or she received rights for reimbursement for asthma medication from the Social Insurance Institution or was registered as having occupational asthma in the Finnish Register on Occupational Diseases. In this study, the concept "persistent asthma" is defined as asthma needing regular medication and fulfilling the criteria for asthma medication reimbursement rights. The date of the application (Social Insurance Institution) or the date of the registration report (Finnish Register on Occupational Diseases) was used as a proxy for the date of diagnosis. As our follow-up was based on the attribution of special reimbursement rights for asthma medication, a person became classified as a case of asthma only when the criteria of these rights were fulfilled, even if he or she may have had asthma-like symptoms before. It could also be that those who had had childhood asthma and who had recovered before 1970 when asthma became eligible for special reimbursement rights and who again were afflicted with asthma during the follow-up after 1985 were classified as incident cases of adult-onset asthma.

\section{Statistical analyses}

The men and women were analyzed separately since the overall incidence of adult onset asthma is higher for women than for men, and this difference applies to Finland as well $(18,19)$. In addition, men and women may perform different tasks in a given occupation, and so their exposure patterns may differ. The incidence rate for the exposure variables, wood dust exposure category, and industrial sector was calculated by summing up the cases and person-years from the three census cohorts and dividing the total number of cases by the accumulated person-years under follow-up in each respective group. Incidence rate ratios [relative risks (RR)] and their $95 \%$ confidence intervals (95\% CI) for the wood-dust exposure categories and woodworkers in 
the selected industries were estimated by a log-linear model (Poisson distributed), using person-years as an offset variable. Age at the start of the follow-up (20-29, $30-39,40-49$, and 50-59 years) was included in the model. Those employed in administrative, managerial, and clerical work in the selected industries were used as a reference group in both models. SAS software (SAS Inc, Gary, NC, USA) was used in the analyses.

The attributable fraction (AF) of the asthma cases caused by occupational exposure in wood-processing industries (ie, the work-related fraction of asthma among woodworkers and other blue-collar workers) was estimated according to the equation $\mathrm{AF}=(\mathrm{RR}-1) / \mathrm{RR}(20)$; the $95 \%$ confidence intervals of the attributable fractions were calculated from the $95 \%$ confidence intervals of the corresponding relative risks. The number of workrelated asthma cases among the woodworkers and other blue-collar workers was determined as $\mathrm{N} \times \mathrm{AF}$, where $\mathrm{N}$ was the number of all asthma cases in a group.

\section{Results}

The incident rates and relative risks for clinically verified asthma among woodworkers and other blue-collar workers in the wood-processing industries in Finland are presented in table 2. Out of all the blue-collar workers (141 197 men, 16937 women) in 10 selected wood-processing industries, $34 \%$ men and $26 \%$ women, respectively, were classified as being exposed to wood dust. The relative risk for asthma was significantly increased for all of the woodworkers among both genders, and an elevated risk was also found for other blue-collar workers employed in the same wood industries. Classification by the intensity of wood dust exposure indicated that, of the male workers, $4 \%$ were persons with high exposure, $8 \%$ had medium exposure, and $23 \%$ had low exposure. The corresponding values for the women were $5 \%, 11 \%$, and $10 \%$. No clear dose-response to wood dust exposure was indicated. Nevertheless, significantly increased relative risks for asthma were found for the groups with low or medium exposure, but not for the group with high exposure (table 2).

From the various sectors of the wood-processing industries, the risk was significantly increased for male woodworkers in 7 of the 10 industrial sectors studied (table 3). The asthma risks were highest in the manufacture of wooden containers (RR 2.5, 95\% Cl 1.3-4.6), and in sawmilling and wood planing (RR $1.9,95 \% \mathrm{Cl}$ 1.5-2.5). For the female woodworkers, the risk was significantly increased in 4 of the 10 industrial sectors, the highest risk being determined for sawmilling and the impregnation of wood (RR 1.8, 95\% Cl 1.3-2.4). The asthma incidence per 1000 person-years did not differ significantly between the woodworkers ( 1.7 for the men and 3.2 for the women) and other blue-collar workers working in wood-processing industries (1.8 for the men, 2.9 for the women) (table 2).

The calculated fraction of asthma cases attributable to work-related factors was $31 \%$ (95\% CI 15-45) for both the male and female woodworkers and $30 \%(95 \% \mathrm{CI}$ $12-43$ ) and $26 \%$ (95\% CI 13-38) for the other male and female blue-collar workers, respectively (table 2).

On the basis of the attributable fractions estimated in table 2, a total of 1213 of all 4074 asthma cases identified in the 10 selected wood industry sectors would be in excess (ie, attributable to work-related factors). However, only 217 were registered in the Finnish Register on Occupational Diseases as occupational asthma, variation occurring between industries. In addition to wood dust, other exposures, such as to formaldehyde, epoxy

Table 2. Incidence rates (per 1000 workers $\times$ year $^{-1}$ ), relative risks (age-adjusted), and work-related attributable fractions (AF) for asthma among male and female workers. The woodworkers have been subdivided according to the exposure-level categories. (RR $=$ relative risk, $95 \% \mathrm{Cl}=95 \%$ confidence interval)

\begin{tabular}{|c|c|c|c|c|c|c|c|c|c|c|c|c|}
\hline \multirow[t]{2}{*}{ Categories } & \multicolumn{6}{|c|}{ Men } & \multicolumn{6}{|c|}{ Women } \\
\hline & Cases & $\begin{array}{c}\text { Popula- } \\
\text { tion }^{a}\end{array}$ & $\begin{array}{l}\text { Incidence } \\
\text { rate }\end{array}$ & $\mathrm{RR}$ & $95 \% \mathrm{Cl}$ & $\begin{array}{l}\mathrm{AF} \\
(\%)\end{array}$ & Cases & $\begin{array}{c}\text { Popula- } \\
\text { tion }^{a}\end{array}$ & $\begin{array}{l}\text { Incidence } \\
\text { rate }\end{array}$ & $\mathrm{RR}$ & $95 \% \mathrm{Cl}$ & $\begin{array}{l}\mathrm{AF} \\
(\%)\end{array}$ \\
\hline Referents $^{b}$ & 86 & 4628 & 1.4 & 1.0 & .. & .. & 223 & 8211 & 2.0 & 1.0 & .. &.$\cdot$ \\
\hline Woodworkers ${ }^{c}$ & 1189 & 50218 & 1.7 & 1.5 & $1.2-1.8$ & 31 & 286 & 6503 & 3.2 & 1.5 & $1.2-1.7$ & 31 \\
\hline Low exposure & 785 & 33226 & 1.7 & 1.4 & $1.1-1.7$ & . & 110 & 2536 & 3.1 & 1.4 & $1.2-1.8$ & . \\
\hline Medium exposure & 317 & 11905 & 2.0 & 1.7 & $1.4-2.2$ & . & 134 & 2742 & 3.7 & 1.6 & $1.3-2.0$ & . \\
\hline High exposure & 87 & 5087 & 1.3 & 1.2 & $0.9-1.6$ & . & 42 & 1225 & 2.6 & 1.2 & $0.8-1.6$ & $\cdot$ \\
\hline Other blue-collar workers ${ }^{d}$ & 2181 & 90979 & 1.8 & 1.4 & $1.1-1.8$ & 30 & 418 & 10434 & 2.9 & 1.4 & $1.2-1.6$ & 26 \\
\hline All blue-collar workers & 3370 & 141197 & 1.8 & 1.4 & $1.1-1.8$ & 30 & 704 & 16937 & 3.0 & 1.4 & $1.2-1.6$ & 29 \\
\hline
\end{tabular}

${ }^{a}$ Arithmetic mean of the population under follow-up in 1986-1990, 1991-1995, and 1996-1998,

${ }^{\mathrm{b}}$ Administrative, managerial, and clerical workers in the selected wood industries.

c Woodworkers in the selected wood industries included the occupations in which direct exposure to wood dust was estimated to occur.

d Other blue-collar workers included the occupations in which exposure to wood dust was unknown. 
Table 3. Incidence rates (per 1000 workers $\times$ year $^{-1}$ ), relative risks (age-adjusted) for asthma in wood industries. (RR $=$ relative risk, $95 \%$ $\mathrm{Cl}=95 \%$ confidence interval)

\begin{tabular}{|c|c|c|c|c|c|c|c|c|c|c|}
\hline \multirow[t]{2}{*}{ Categories } & \multicolumn{5}{|c|}{ Men } & \multicolumn{5}{|c|}{ Women } \\
\hline & Cases & $\begin{array}{l}\text { Popula- } \\
\text { tion }^{a}\end{array}$ & $\begin{array}{l}\text { Incidence } \\
\text { rate }\end{array}$ & $\mathrm{RR}$ & $95 \% \mathrm{Cl}$ & Cases & $\begin{array}{c}\text { Popula- } \\
\text { tion }^{a}\end{array}$ & $\begin{array}{l}\text { Incidence } \\
\text { rate }\end{array}$ & $\mathrm{RR}$ & $95 \% \mathrm{Cl}$ \\
\hline Referents $^{b}$ & 86 & 4628 & 1.4 & 1.0 & .. & 223 & 8211 & 2.1 & 1.0 & .. \\
\hline Woodworkers ${ }^{c, d}$ & 1189 & 50218 & 1.7 & 1.5 & $1.2-1.8$ & 286 & 6503 & 3.2 & 1.5 & $1.2-1.7$ \\
\hline Forestry and logging (02.0) & 320 & 13145 & 1.8 & 1.5 & $1.2-1.8$ & $8^{c}$ & 256 & . & . & . \\
\hline Sawmilling (20.1) & 173 & 5647 & 2.3 & 1.9 & $1.5-2.5$ & 55 & 995 & 4.0 & 1.8 & $1.3-2.4$ \\
\hline Manufacture of wooden boards (20.2) & 55 & 2006 & 2.1 & 1.7 & $1.2-2.5$ & 76 & 1541 & 3.7 & 1.6 & $1.3-2.1$ \\
\hline Manufacture of builders' carpentry (20.3) & 103 & 4375 & 1.7 & 1.6 & $1.2-2.2$ & 45 & 922 & 3.7 & 1.7 & $1.2-2.5$ \\
\hline Manufacture of wooden containers (20.4) & 11 & 327 & 2.7 & 2.5 & $1.3-4.6$ & $1^{c}$ & 60 & . & . & . \\
\hline Manufacture of other wood products (20.5) & 15 & 652 & 1.7 & 1.5 & $0.9-2.6$ & $3^{c}$ & 123 & . & . & . \\
\hline Building and repairing ships and boats (35.1) & 15 & 1113 & 1.0 & 0.9 & $0.5-1.5$ & $7^{c}$ & 290 & . & . & . \\
\hline Manufacture of furniture (36.1) & 65 & 4084 & 1.2 & 1.1 & $0.8-1.5$ & 26 & 952 & 2.0 & 0.9 & $0.62-1.40$ \\
\hline Building of complete constructions (45.2) & 412 & 17973 & 1.7 & 1.3 & $1.1-1.7$ & 62 & 1301 & 3.4 & 1.5 & $1.1-2.0$ \\
\hline Building completion (45.4) & 20 & 895 & 1.8 & 1.7 & $1.1-1.8$ & $3^{c}$ & 63 & . & · & . \\
\hline
\end{tabular}

a Arithmetic mean of the population under follow-up in 1986-1990, 1991-1995, and 1996-1998.

${ }^{\mathrm{b}}$ Administrative, managerial, and clerical workers in the selected wood industries.

c If the number of cases was $<10$, the incidence rates and relative risks have not been reported.

${ }^{d}$ Code of the economic activity (see the Classification of Occupation of the Persons and the Economic Actvitiy of their Employers) in parentheses.

Table 4. Estimated work-related asthma cases and reported occupational asthma cases among the workers in the 10 wood industry sectors in the Finnish Register on Occupational Diseases in 1986-1998.

\begin{tabular}{|c|c|c|c|c|}
\hline \multirow[t]{2}{*}{ Industrial sectors ${ }^{\text {a }}$} & \multirow{2}{*}{$\begin{array}{l}\text { Cases } \\
(\mathrm{N})\end{array}$} & \multirow{2}{*}{$\begin{array}{l}\text { Estimated } \\
\text { work- } \\
\text { related } \\
\text { cases }^{b}(\mathrm{~N})\end{array}$} & \multicolumn{2}{|r|}{ Finnish Register on Occupational Diseases } \\
\hline & & & $\begin{array}{l}\text { Cases } \\
(\mathrm{N})\end{array}$ & Coded causative agent \\
\hline Forestry, logging and related services (02.0) & 328 & 99 & 1 & Animal epithelium \\
\hline Sawmilling and planing of wood and impregnation of wood (20.1) & 228 & 107 & 18 & Spruce; wood not specified \\
\hline Manufacture of wooden and fiber boards (20.2) & 131 & 52 & 39 & $\begin{array}{l}\text { Isocyanates; formaldehyde; molds; pine; spruce; birch; } \\
\text { glues }\end{array}$ \\
\hline Manufacture of builders carpentry and joinery (20.3) & 148 & 58 & 28 & $\begin{array}{l}\text { Isocyanates; formaldehyde; pine; obeche; wood not } \\
\text { specified }\end{array}$ \\
\hline Manufacture of wooden containers (20.4) & 12 & 6 & - & \\
\hline Manufacture of other products of wood (20.5) & 18 & 4 & 9 & Formaldehyde; pine; obeche; wood not specified \\
\hline Building and repairing of ships and boats (35.1) & 22 & - & 1 & Teak \\
\hline Manufacture of furniture (36.1) & 91 & 4 & 13 & Formaldehyde; spruce; beech \\
\hline Building of complete constructions (45.2) & 474 & 123 & 10 & Isocyanates; paints; pine; obeche \\
\hline Building completion (45.4) & 23 & 10 & 1 & Epoxy paints; obeche \\
\hline Woodworkers & 1475 & 468 & 119 & $\cdot$ \\
\hline Other blue-collar workers & 2599 & 745 & 98 & . \\
\hline
\end{tabular}

a Code of the economic activity (see the Classification of Occupation of the Persons and the Economic Actvitiy of their Employers) in parentheses.

b The estimated cases have been calculated on the basis of the work-related attributable fractions and the numbers of cases in table 3 .

compounds, isocyanates, microorganisms, or glues, have been registered in the Finnish Register on Occupational Diseases as causative agents for occupational asthma in wood-processing sectors (table 4).

\section{Discussion}

We found significantly elevated risks of asthma both for wood workers and other blue-collar workers employed in wood-processing industries. In our study, the case ascertainment was accomplished through two national registers that rely on diagnoses made by pul- monary specialists based on strict clinical criteria for a persistent form of asthma (asthma needing regular medication). This definition is rather specific but, at the same time, more restrictive than those typically used in epidemiologic studies. Consequently, using such a definition as physician-diagnosed persistent asthma will result in high specificity and low sensitivity, and it may in fact underestimate the frequency of asthma. The excess observed in association with work may represent two types of disease, new-onset persistent asthma without a history of asthma or preexisting mild disease that the work-related exposure may have aggravated so that it deteriorated sufficiently to fulfill the criteria 
for reimbursement established by the Social Insurance Institution of Finland.

In the wood-processing industries, the asthma incidence rates were equally elevated among the wood workers and other blue-collar workers when they were compared with an unexposed (white-collar) reference group from the same industries. The wood workers in this study were grouped according to the intensity of wood dust exposure. However, part of other blue-collar workers has also been exposed to wood dust, and other respiratory irritants and allergy-causing airborne contaminants are present in these industries. Both the woodworkers and other blue-collar workers may have been exposed to such other exposures. This possibility could mean either that even a rather low exposure to wood dust can increase the risk of developing persistent asthma or it could be that, in the group of other bluecollar workers, also other (nonwood dusts) industrial exposures play an important role. There is increasing evidence that asthma and other respiratory symptoms occur already at low wood dust levels $(11,16,21)$. The relation between occupational exposures and asthma is complicated. Generally, a single causal agent is identified as a causative agent in occupational asthma, whereas wood dusts and emissions from fresh wood are complex mixtures of chemicals, particles, and biohazards that make it more difficult to ascribe causality.

Although the relative risk for wood workers was significantly elevated and the analysis by intensity of wood dust exposure revealed significantly increased asthma risks in the low- and medium-exposure groups, no dose-response relationship between the level of wood dust exposure and asthma was found. However, there are several factors that may have affected the dose-response relationships. In addition to evidence for respiratory health effects at low wood dust levels, early in employment, workers may choose to quit when ill or when work conditions are perceived to cause illness such as asthma. It has been shown that changing jobs because the current one is causing respiratory symptoms is frequent before the diagnosis of asthma (22). Finally, the nondifferential misclassification of exposure may cause bias away from the null in the medium category, whereas the overall exposure-response trend will usually be biased towards the null (23).

The differences between the risk estimates in different industries were small, although the exposure patterns of the workers differed. Wood handled in sawmills and in wooden board industries is fresh, whereas it is dry, for example, in the furniture industry. Over $95 \%$ of the wood used in Finnish sawmills is either pine or spruce, the rest being birch (24). Fresh softwood wood can emit monoterpenes (25) and resin acids (26). Resin acids are wellknown allergens; these causative agents are believed to be peroxides formed from abietic acid in intense heat
(27-30). Several authors have postulated that some of the respiratory symptoms reported for woodworkers could be due to exposure to microbe-related agents (eg, endotoxins) (31-33). In other, questionnaire-based studies, sawmill workers exposed to coniferous tree species and to other exposures have also reported current asthma more often than referents $(11,13)$. In Finland, the occupational disease register (Finnish Register on Occupational Diseases) lists a few well-documented cases of occupational asthma caused by exposure to dusts from spruce or pine (table 4). Such diagnoses have been clinically verified by bronchial challenge tests using inhalable preparations of wood dust.

An obvious question in considering the findings of our study is whether the comparison of the asthma incidence of the blue-collar workers with that of the administrative employees (managers, clerks) is valid. If the risk of asthma were clearly related to the social class of the employees, the finding would be distorted by confounding. Many administrative employees belong to a higher social class than blue-collar workers do. Our analysis is part of a larger study of asthma incidence in the employed workforce of Finland, which used administrative, managerial, and clerical work as reference (1, 34). To examine the possible effect of social class on the results, we performed separate analyses using as reference only the lower-level administrative employees (secretaries, office clerks, bookkeepers, and similar occupations). The incidence rate of the lower-level administrative employees was similar to that of administrative workers in general and did not change the relative risks of the exposed occupations. We have also considered potential confounding by smoking differences and concluded that it is unlikely that such differences would have significantly biased our risk estimates $(1,34)$.

In conclusion, we found an increased incidence of asthma in wood-processing industries, not only for wood workers directly exposed to wood dust but also for other blue-collar workers employed in the same wood industry sectors. In both of these groups, the attributable fraction of the work-related factors of the asthma incidence was about $31 \%$. Cases recognized as occupational asthma accounted for only a small part of the total asthma excess. This finding indicates that much of the work-related asthma excess remains unrecognized in these industries.

\section{Acknowledgments}

We are indebted to Marianne Johnson from Statistics Finland, Timo Klaukka from the Finnish Social Insurance Institution, and Anja Saalo and Ilpo Mäkinen from the Finnish Register on Occupational Diseases for their assistance in creating the data files. 


\section{References}

1. Karjalainen A, Kurppa K, Martikainen R, Klaukka T, Karjalainen J. Work is related to a substantial portion of adult - onset asthma incidence in the Finnish population. Am J Respir Crit Care Med. 2001;164:565-8.

2. Yelin E, Henke J, Katz PP, Eisner MD, Blanc PD. Work dynamics of adults with asthma. Am J Ind Med. 1999;35(5):472-80.

3. Balmes J, Becklake M, Blanc P, Henneberger P, Kreiss K, Mapp C, et al. American Thoracic Society Statement: occupational contribution to the burden of airway disease. Am J Respir Crit Care Med. 2003;167(5):787-97.

4. Meredith SK, Taylor VM, McDonald JC. Occupational respiratory disease in the United Kingdom 1989: a report to the British Thoracic Society and the Society of Occupational Medicine by the SWORD project group. Br J Ind Med. 1991;48(5):292-8.

5. Contreras GR, Rousseau R, Chan-Yeung M. Occupational respiratory diseases in British Columbia, Canada in 1991. Occup Environ Med. 1994;51(10):710-2.

6. Venables KM, Chan-Yeung M. Occupational asthma. Lancet. 1997;349(9063):1465-9.

7. van Kampen V, Merget R, Baur X. Occupational airway sensitizers: an overview on the respective literature. Am J Ind Med. 2000;38(2):164-218.

8. Documentation of the threshold limit values and biological exposure indices: wood dusts. 7 th edition. Cincinnati $(\mathrm{OH})$ : The American Conference of Governmental Industrial Hygienists $\AA 2005$.

9. Scientific Committee for Occupational Exposure Limits, SCOEL. Recommendations of the Scientific Committee on Occupational Exposure Limits: risk assessment for wood dust. Luxembourg: European Commission, DG Employment and Social Affairs DG; 2003 [cited 9 October 2007]. Available at: http://ec.europa.eu/employment_social/health_safety/docs/ sum_102.pdf.

10. Noertjojo HK, Dimich-Ward H, Peelen S, Dittrick M, Kennedy SM, Chan-Yeung M. Western red cedar dust exposure and lung function: a dose-response relationship. Am J Respir Crit Care Med. 1996;154(4 Pt 1):968-73.

11. Douwes J, McLean D, Slater T, Pearce N. Asthma and other respiratory symptoms in New Zealand pine processing sawmill workers. Am J Ind Med. 2001;39(6):608-15.

12. Lin FJ, Dimich-Ward H, Chan-Yeung M. Longitudinal decline in lung function in patients with occupational asthma due to western red cedar. Occup Environ Med. 1996;53(11):753-6.

13. Hessel PA, Herbert FA, Melenka LS, Yoshida K, Michaelchuk D, Nakaza M. Lung health in sawmill workers exposed to pine and spruce. Chest. 1995;108(3):642-6.

14. Malo JL, Cartier A, L'Archeveque J, Trudeau C, Courteau JP, Bherer L. Prevalence of occupational asthma among workers exposed to eastern white cedar. Am J Respir Crit Care Med. 1994;150(6 Pt 1):1697-701.

15. Schlunssen V, Schaumburg I, Heederik D, Taudorf E, Sigsgaard $\mathrm{T}$. Indices of asthma among atopic and non-atopic woodworkers. Occup Environ Med. 2004;61(6):504-11.

16. Schlunssen V, Schaumburg I, Taudorf E, Mikkelsen AB, Sigsgaard T. Respiratory symptoms and lung function among Danish woodworkers. J Occup Environ Med. 2002;44(1):82-98.

17. Liukkonen T, Zitting A, Heikkilä P, Husgafvel-Pursiainen K. Puupöly [Wood dust]. In: Vainio H, Liesivuori J, Lehtola M, Louekari K, Engström K, Kauppinen T, et al, editors. Kemikaalit ja työ: selvitys työympäristön kemikaaliriskeistä [Chemicals and work: report of chemical risks at work]. Helsinki: Finnish Institute of Occupational Health; 2005. p 54-61.

18. Pallasaho P, Lundback B, Laspa SL, Jonsson E, Kotaniemi J, Sovijärvi AR, et al. Increasing prevalence of asthma but not of chronic bronchitis in Finland?: report from the FinEsS-Helsinki Study. Respir Med. 1999;93(11):798-809.

19. Reijula K, Haahtela T, Klaukka T, Rantanen J. Incidence of occupational asthma and persistent asthma in young adults has increased in Finland. Chest. 1997;110:58-61.

20. Rothman KJ, Greenland S. Epidemiology. 2nd edition. New York (NY): Lippincott Raven; 1997.

21. Demers PA, Teschke K, Kennedy SM. What to do about softwood?: a review of respiratory effects and recommendations regarding exposure limits. Am J Ind Med. 1997;31(4):385-98.

22. Kogevinas M, Anto JM, Soriano JB, Tobias A, Burney P. The risk of asthma attributable to occupational exposures: a population-based study in Spain. Am J Respir Crit Care Med. 1996;154(1):137-43.

23. Birkett NJ. Re: "When will nondifferential misclassification of an exposure preserve the direction of a trend?". Am J Epidemiol. 1995;142(7):783-4.

24. Kauppinen T, Vincent R, Liukkonen T, Grzebyk M, Kauppinen A, Welling I, et al. Occupational exposure to inhalable wood dust in the member states of the European Union. Ann Occup Hyg. 2006;50(6):549-61.

25. Rosenberg C, Liukkonen T, Kallas-Tarpila T, Ruonakangas A, Ranta R, Nurminen M, et al. Monoterpene and wood dust exposures: work-related symptoms among Finnish sawmill workers. Am J Ind Med. 2002;41(1):38-53.

26. Demers PA, Teschke K, Davies HW, Kennedy SM, Leung V. Exposure to dust, resin acids, and monoterpenes in softwood lumber mills. Am Ind Hyg Assoc J. 2000;61(4):521-8.

27. Smith PA, Gardner DR, Drown DB, Downs G, Jederberg WW, Still K. Detection of resin acid compounds in airborne particulate generated from rosin used as a soldering flux. Am Ind Hyg Assoc J. 1997;58(12):868-75.

28. Smith PA, Gardner DR, Drown DB, Jederberg WW, Still K. Oxidized resin acids in aerosol derived from rosin core solder. Am Ind Hyg Assoc J. 1998;59(12):889-94.

29. Sadhra S, Foulds IS, Gray CN. Identification of contact allergens in unmodified rosin using a combination of patch testing and analytical chemistry techniques. Br J Dermatol. 1996;134(4):662-8.

30. Keira T, Aizawa Y, Karube H, Niituya M, Shinohara S, Kuwashima A, et al. Adverse effects of colophony. Ind Health. 1997;35(1):1-7.

31. Dahlqvist M, Johard U, Alexandersson R, Bergstrom B, Ekholm $\mathrm{U}$, Eklund A, et al. Lung function and precipitating antibodies in low exposed wood trimmers in Sweden. Am J Ind Med. 1992;21(4):549-59.

32. Halpin DM, Graneek BJ, Lacey J, Nieuwenhuijsen MJ, Williamson PA, Venables KM, et al. Respiratory symptoms, immunological responses, and aeroallergen concentrations at a sawmill. Occup Environ Med. 1994;51(3):165-72.

33. Alwis KU, Mandryk J, Hocking AD. Exposure to biohazards in wood dust: bacteria, fungi, endotoxins, and (1-->3)-beta-Dglucans. Appl Occup Environ Hyg. 1999;14(9):598-608.

34. Karjalainen A, Kurppa K, Martikainen R, Karjalainen J, Klaukka T. Exploration of asthma risk by occupation—extended analysis of an incidence study of the Finnish population. Scand J Work Environ Health. 2002;28(1):49-57.

Received for publication: 6 March 2007 